\title{
How Family Firms Can Innovate With Less
}

\section{Alfredo De Massis (Free University of Bozen-Bolzano)}

KEYWORDS: Entrepreneurship, Family Business, financing.

Family firms often face limits on the financial and human capital available to them. But in Germany, a class of small- to medium-sized businesses known as the "Mittlestand" has learned to transcend these limits and innovate anyway, accounting for a half million firms and $\$ 8.7$ billion in R\&D spending in 2010 . Familybusiness.org editor Alfredo De Massis, Professor of Entrepreneurship \& Family Business at the Free University of Bozen-Bolzano, and colleagues David Andretsch, Lorraine Uhlander and Nadine Kammerlander researched what made the Mittlestand so successful. Their findings, entitled "Innovation with Limited Resources: Management Lessons from the German Mittlestand," (https://onlinelibrary.wiley.com/doi/abs/10.1111/jpim.12 373) were published in January 2018 in the Journal of Product Innovation Management. This video, published with permission from the four authors, summarizes the six things that have helped make the Mittlestand strong and successful. 